\title{
The Economic Functions of Cross-Border Activities of Skouw Sae Community, Jayapura
}

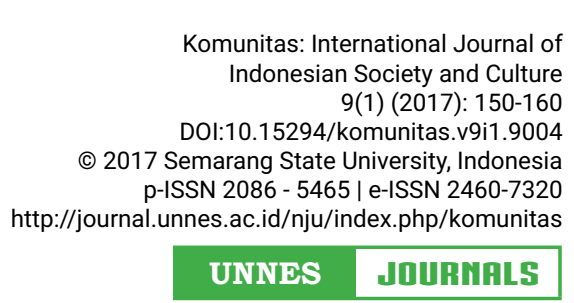

UNNDS JOURNALS

\author{
He Usman' ${ }^{1}$ Sjafri Sairin² \\ ${ }^{1}$ Training and Education Center for Social Welfare, Jayapura. Indonesia \\ ${ }^{2}$ Faculty of Cultural Sciences, Gadjah Mada University, Jogjarakta, Indonesia
}

Received: 3 January 2017; Accepted: 3 March2017; Published: 30 March 2017

\begin{abstract}
This article aims to illustrate the economic functions of cross-border done by Skouw Sae community residents, Muara Tami District, Jayapura City to Wutung Vanimo Village, Papua New Guinea (PNG) using ethnographic approach. This study reveals seven economic functions of cross-border activity. These seven functions include fulfilling the family's nutritional needs of a long-term food preparation idea system, apprehending the meaning of the land as a source of life, meeting the needs of salvation through protection and defense of religion through purchasing beverages for Christmas and leaving the idea system of Jesus Christ as the source Love, fulfilling the need for relaxation through school vacation activities and inheriting the idea system of the need for a refresher to familiarize the family, meeting the needs of the movement through village leaders' visits to bring the leaders of the two communities together and inherit the idea system of formal and symbol leaders, meeting the needs of growth through traditional educational activities within the family and inheriting a system of ideas for the necessity of teaching for men. In conclusion, the economic function of cross-border activity is not only done to fulfill basic needs, but also the institutional needs and symbolism of local residents.
\end{abstract}

\section{Keywords}

cross-border; Skouw Sae community; function of economic activity

\section{INTRODUCTION}

The traditional cross-border activities between countries driven by economic, social, political and cultural aspects are often found on the border areas among African countries (Adepujo 1996), America-Mexico (Cohen 2004), Indonesia-The Philippines (Zaelany \& Augustina 1995), IndonesiaMalaysia (Siagian 1995; Djohan \& Yogaswara 1998 ), Indonesia-Timor Leste (Setiawan 2004) and Papua (Indonesia)-Papua New
Guinea (PNG) (Wenehen 2000; Bandiyono 2004). In Papua border, such activities are often conducted by 7 Papuan sub-ethnics as the sub-ethnics of Skouw and Moso in Muara Tami District, Jayapura City, sub-ethnic of Manem in East Arso District, sub-ethnic of Walsa in Waris District, sub-ethnic of

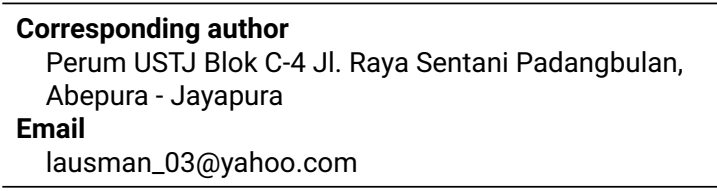


Humbuluk in Senggi District, sub-ethnic of Emem in Web District, and sub-ethnic of Ndra in Web and Towe Districts in Kerom Regency, sub-ethnic of Ngalum in Pegunungan Bintang Regency, sub-ethnic of Muyu in Boven Digul Regency and sub-ethnic of Marind-anim in Merauke Regency (Mansoben 2008, p. 7). The mobility of Skouw Sae village residents to Wutung village in PNG is repeatedly conducted because of economic, cultural and social factors.

Therefore, the study tries to investigate what are the internal factors which become driving and inhibiting factors for the process of cross-border of Skouw Sae Village communities based on the factors of fulfillment of basic and institutional needs as well as aspects of life symbolism of community in this village. The second is to identify the driving and inhibiting factors of cross-border process including inhibition of mobility based on origin, destination and intermediate obstacles which affect mobility across the borders. The third is to investigate the economic functions of cross-border activity performed by Skouw Sae Village people to Wutung Village in PNG.

This study gives a new addition to the existing limited research about cross border activities. These studies include among others the researches done by Pitelis \& Teece (2010), Ghosh (2011), Weidenfeld (2013), and Meuleman \& Wright (2011).

Under functionalism perspective of Malinowski (1944, p. 44), each custom functions to meet basic needs as a minimum requirement so that people will be able to survive. According to Malinowski in Bohannan (1988, p. 277), there are seven human needs such as: nutrition, reproduction, shelter, comfort and well-being, safety, relaxation, movement and growth. The above seven needs are the necessary elements to maintain physical and psychological balance. The balance aims to maintain life and health of someone (Lundquist 2013; Newman 2011; Amelina 2012). The demand for the fulfillment of the above needs encourages the cross-border activity in an organized manner that involves the elements of people, reasons and objectives, specific targets for the participation of its members, norms, activities, facilities and certain functions (Meuleman 2011; Bertrand 2012; Xheneti 2013; Lane 2011). It also encourages the use of collective rules or agreements in the form of a system of ideas based on culture, belief and religion, art and the ceremony of the village community to legitimize, regulate and guide cross-border behavior (Pitelis 2010; Ghosh 2011; Xia 2011; Weidenfeld 2013). According to Lee (1966), migration process is influenced by four factors: the first is the driving factor in the area of origin; the second is the inhabiting factors in the destination area, the third is the barrier factors and the fourth is personal factors covering a very broad aspect.

The targets of the research were traditional border-crossers for economic activity. Their activities were tracked from the information recorded on the Skouw CrossBorder Checkpoint, as well as the direct information from the people. According to Malinowski in Kuper (1996, pp. 15-16), there were three groups of the data: the first was the institutional and customary framework data which was studied using statistical documentation methods with concrete evidence, the second was data which was obtained by observing the actual social action and carefully recording everything in a particular ethnographic book, the third was a collection of ethnographic statements from informants, narrative characteristics of physical and socio-cultural conditions, as well as other related elements. This study employed qualitative research technique to obtain information on some types of needs that existed at the level of basic needs, social structures and symbols and had links to the economic functions of cross-border activities. The study also investigated the driving and inhabiting economic reasons of cross-border activities. To obtain the stated data, the study used participant observation based on their activity.

\section{Geographical Setting}

Geographically, the two villages are located on the border of the two countries separated by traditional delimitation of Tami Ri- 
ver. Politically, they are separated by a flare tower as well as the border gate of both countries. Cross-border activities from both countries are motivated by the closeness of the two communities. The kinship of the two communities stems from the marriage between Wutung women and Skouw Sae men as a solution to end the murderous conflict of Skouw Sae women. The descendants of the marriage are called as jo pa lala or the descendants of Skouw Sae and Wutung. The presence of Wutung residents was due to diseases so they were settled in Skouw Sae which also helped to strengthen the kinship. The existence of second community marriages from both communities also strengthened the relationship that had existed previously. The descendants and Wutung residents who came later and got settled in Kampung Skouw Sae and the residents of Skouw Sae who are now living in Wutung. The reasons are because of marriage and customary land in the area of origin that are kept by their relatives. They also have proximity to indigenous/village leaders in the area of origin so they are often invited over. They will bring food to support the consumption of cultural activities involving the masses from within and outside the village. The residents of both villages have an economic relationship which is originally built through a barter system then is later changed to a market system. Both communities also have something in common, called manded and ifu dance which tells the journey of the ancestors of Sae Skouw community from Wutung, and have a common cultural values characteristic. According to Held in Suparlan (1995, pp. 37-39), the people easily accept and take over something else that is more culturally advanced or more suitable due to the low technology owned by them, then incorporated it with the local culture.

In addition, cross-border activities are also encouraged by the desire to fulfill people's basic needs which cannot be fulfilled in the area of origin or is still very dependent on the income of family economic activities in the area of Wutung. The example for this is the demands of the fulfillment of family nutrition for food based on work thinking systems for the long term. The demands of financial stability for some families to reproduce needs is based on a thinking system for family, clan and community is continued through the payment of dowry in the area of origin or Wutung from male family according to the quantity requested by the female family. The demand for comfort and family welfare is based on house thinking system as a place to form family and to plan various family activities. Therefore, it needs to be supported by procurement of individual and family equipment. Also, it needs as compensation of a wife who is passed away from a male family to his wifess family based on a system of thought to remove the seed of hostility between the male family and the wifess family and between the two communities. The demands for the fulfillment of safety requirements is conducted through the provision of drinks for the celebration of Christmas as well as to support the rituals in the traditional house of tangfa which is based on a system of thought for closer relations with each other and supernatural powers. The demand for relaxation needs is conducted through relaxation during school holidays, custom dance activities at traditional houses, gift exchange between Skouw and Wutung women, and sport activities in Wutung village based on a thinking system of building closer kinship. In order to meet the needs of both communities to be closer, the village leader's visits are regularly held based on a thinking system to reduce the conflict between the two communities. Also, the demands of meeting the needs of growth is based on thinking systems for customary learning activities tangfa to deal with every phase of human life.

In addition, there is also a demand for income from economic activities to support the activities of residents in the village environment, such as social relations in the activities of worship. Religious activities are done weekly in the church and worship elements and attended by fathers, mothers, teenagers and children. The treatment system at Skouw community is conducted 
through health center, village government and customary government, integrating facilities for citizens through football and volleyball activities, and custom dance activities together at the end of each year.

\section{The Driving and Inhibiting Factors of Cross-Border Activities}

The driving factors of cross-border activities in the economic aspect from the original area is as a result of government policy since the integration of this region to the Unitary State of the Republic of Indonesia (NKRI) until before the implementation of special autonomy that has not rested on the economic empowerment of border communities. Therefore, the villagers are still experiencing social and economic problems quite seriously. The reduced forest area due to transmigration program in East Koya impacts on the activities of gathering and hunting residents to be far from the village area. The success of the program activities of the village empowerment strategic plan is due to the mentoring and monitoring process from the technical field officers who are not working well. There is lack of bank support and economic institutions, including limited access to markets and information on agricultural commodities which have little impact on production and distribution activities. The displacement of local people in the border market activity by the migrant traders due to the weakness of the market management pattern causes many of those who return to pursue subsystem economic activities. The strength of kinship ties between villagers has hindered small-scale business activities funded from village empowerment plans. The big number of family members in a household burdens the family expenditure. All of the above factors have an impact on the high dependence of some people on economic activities in Wutung region. In addition, the limited sale of canned drinks from the PNG region is much-loved by local residents at Christmas time. And, there is limited cultural and social activities involving local citizens with their customary leaders from their home regions.
There are some driving factors of cross-border to Wutung village. The factors include; from the economic point of view, the high production of betel nut with good quality and quantity that many consumers demand in Jayapura City, Mimika and Wamena. The availability of customary land is used for gardening, hunting, and gathering to meet the needs of family food. People also use the potential of marine resources in Wutung region that can be cultivated freely through agreements that have long been institutionalized by both leaders of communities. Therefore, the income of the three economic activities influences the fulfillment of other needs.

Another driving factor is the availability of canned drinks that many people love on Christmas celebrations at an affordable price. In terms of culture, such as, the invitation of traditional leaders to follow the ceremony of building a cemetery, thanksgiving customary house, crowning traditional leader, dowry payment, and head payment (compensation for a deceased mother). From a social point of view, at the village level, there is an invitation from the committee to attend a friendly match in celebrating the Independence Day of PNG, and the invitation to gifts exchange among fellow women in both villages. For the family reason, they have some interesting places for family recreation activities during school holidays and the desire to get closer relations between the two village leaders. All of the above factors have become the driving factors for people to do crossborder activities.

There are also three inhabiting factors for the mobility in the origin area. The first is family aspect, such as the high solidarity in the household which becomes an obstacle to cross borders. For example, there is one family member who is experiencing certain sickness so it is difficult to abandon, the absence of other family members in taking care of a child who is still attending school and the business of the husband and wife who are still managing their land clearing. The second is community aspect because of the high level of community 
solidarity prevents people from crossing borders. The examples are the death of a resident in the village and also the cultural values at the community level. The activities on Saturday and Sunday are avoided by the village residents because they use it for church breaks. The thrd is the state reason where these barriers are more based on the development of security conditions in the environment of Jayapura City, as well as the environment around the border of the two countries. For example, the welcoming of the election, the Independence Day of the Republic of Indonesia (RI), the occurrence of military contacts with gangs of Free Papua Organization (OPM) in this region, and before the celebration of OPM anniversary every December 2, often closes the border gates of both countries up to a month.

There are also three inhibiting factors of cross border activities in the destination area. First, at the family level, such as the presence of sick family members, the family members who take care the plants in the garden, and the presence of a guest of relatives who stay from other villages. At the community level is strong solidarity with the community. For example, the residents of Wutung PNG who are died and cultural activities led by custom leaders, then all citizens must be involved together. Thirdly, at the state level, such as, the handling of criminal cases (murder, interethnic fights) around Vanimo City, ahead of the election, and the celebration of the independence day of PNG have an impact on the closing of the border gate. The inhibiting factors in the destination area are at the family level lasts from one to two weeks. At the community level, it can last for a week. At the country level, it can last between two weeks to a month. There are also obstacles such as the necessity to use the Border Crossing Card (KLB) approved by the immigration officers of RI and PNG.

\section{Economic Functions of Cross-Border Activities}

First, the activity aims at meeting the increasing needs of family to food through the purchase of betel nut, gardening and sea products. The sale and purchase activities of betel fruit between Skouw Sae and Wutung women who still have a kinship relationship provides income for the families of both communities. Gardening activities within the Wutung customary territory according to the division of labor has provided family income for the fulfillment of citizens> needs. Increasing family income is done through expansion of area of betel nut collection in production centers. Also, the application of intensive gardening patterns is supported by the use of equipment and fertilizers to increase production and manufacture of more than one garden to maintain the production sustainability. The marketing of betel nut commodities is done through social and marketing networks with middlemen from Abepura City who then sell them to Mimika and Wamena regencies. Meanwhile, the commodity of moor marketing is done through social and marketing networks with the middlemen of west and East Koya Barat which then sell them to Abepura market and around Jayapura City to obtain better income. The results of fishing activities are generally used to meet the needs of animal protein for their family. Others are filled with hunting and utilizing the resources of Tami River and swamps as well as lakes found around the village. The activities to set the sail for the Wutung region simultaneously support a ban on the use of natural resources (hoo, sasi) imposed by custom leaders against the territorial sea, river, lake and forest with all its contents, for 1 to 2 months prior to the activities of customs or church involving the masses. It is also imperative to open up the moor land in the territory that the custom leaders have specified in order not to damage the natural environment. The efforts to control the utilization of such natural resources are also found in the Yokari community (2016, p. 281). According to Poespowardojo (1989, p. 113), such attitude is intended to prevent excessive exploitation of natural resources in the area so as to disrupt the existence of this community.

The above three economic activities play an essential role to meet the needs of 
family for food. This also affects the types of food consumed by citizens. Each village family is now consuming rice, meat and eggs that are often purchased in Abepura market. The variations of this type of food have become part of the diet of each family of this village. The ingredients are partly purchased by women from the market or taken from the garden, then processed in the kitchen and served for family consumption in the morning, afternoon and evening. The economic activities are based on a system of working ideas to meet the family's food supply and to preserve the meaning of land in this community as life support and the need to regulate the utilization of natural resources for the survival of family, clan, and community in the village. The above three economic activities also support the fulfillment of other needs in the form of provision of transportation funds, food ingredients, and funds for social obligations. The obligation includes the supporting payment of dowry in the form of beads and funds to male families to meet the demand of female families in order to meet the needs of female and male sexual urges in order to maintain group continuity. This activity is also useful in maintaining relationships in marriage as a basis for forming a family that Malinowski in Kuper (1996, p. 28) is seen as a place to create the personality, the primary emotion of humankind. The family, as confirmed by Herskovits (2006, p. 85), serves as the highest role in disciplining children. Through the role of father, basic and advanced knowledge about the culture of the local community is continuously inherited. Meanwhile, for the female family, dowry payment is regarded as a symbol of respect for self-esteem, as well as creating an extended family that sustains community activities.

Economic function for prospective husbands is to improve their familyss economy. The presence of the wives helps the fulfillment of family economic needs through the division of labor on mooring activities. Also, they are expected to give birth to a son thus strengthening his position in the community. According to
Claessen in Soekardjo (1987, p. 30), the use of the name of the clan in the patrilineal kinship system is the basis to demand the social status of the clan along with the right of succession families in the form of land and property. Therefore, they can perform their duty to support their working parents who cannot work as well as his unmarried sisters. This activity is useful as a binding system for the male family with his wife>s family, including other families in the local community. Hence, this activity can renew social relationships and maintain solidarity among them. Finally, this activity is also based on the idea of dowry payment system which serves as the basis for building a family.

Fresh fund is used as compensation according to ability to a husband whose wife died. This aid is then given to the wifess family. It aims to meet the needs of the comfort and welfare of the families of women who died. This gift is regarded as a manifestation of a male family»s respect for their family members who have given offspring and played a role throughout their lives in clan, community and even outside the community as well as in domestic, reproductive and economic affairs. This action also serves as a social sanction against her husband who can no longer care and keep his wife or child well. In the broad aspect, this gift is expected to preserve and eliminate the seeds of hostility, maintain good relationships between husband and wife, maintain the bonding relationship between the child, husband and his wifess family, between the husband ss clan and his wifes clan and the two communities in general. Finally, this activity is based on the idea of compulsion to pay compensation from the husbandss family to his wifess family.

They also support the construction of graves celebration, traditional houses as well as the coronation ondoaf in Wutung Village. The activities are done to meet the needs of well-being of individuals through the social control of the elements of the traditional leaders of both Ondoafi, inside messenger, outside messenger and clan lea- 
ders who by Georges Balandier in Budisanto (1986, p. 51) refers to as a social authority in the form of protection, safeguard, and take responsibility for the problems, including resolving the misunderstandings that occur among the clan members and arrange the use of land for the clan members. It also supports the members of the clanss deceased family by providing land for economic activity. In addition, this activity is also important to maintain the existence of traditional institutions in managing the equality among groups, institutions and different interests in the community by using power with sanctions. Hence, there is no collision between them in living together. It also ensures and implements law and order within the community using explicit sanctions in both material and moral forms. All these things provide the comfort and prosperity of individuals and families. Finally, this activity is based on a system of ideas on the need to maintain the traditional leadership of the village community.

The economic activity also supports the needs to purchase canned drinks for Christmas celebrations annually with the aim of meeting the needs of safety through protection and defense of religion. Almost all of these villagers are Protestant Christian. The peopless religion is manifested in the form of a sacred text in the local language containing Godss commandments, instructions, and prohibitions, interpreted and obeyed by his adherents in daily life. The reference to that interpretation is the ethnic culture in question. Thus, celebration over religion is preserved as a source of life values in their social or emotional religious and cultural actions. Kluckhon in Kessing (1998, p. 94) states that religion provides several benefits. First, it gives testimony and answers the questions of the existence of how the origin of the world, how the relationship between humans with other species, why humans can succeed and fail. Second, it authorizes the forces in the universe that controls and sustains the social order by giving an atmosphere that cannot be contested. Third, it increases human ability to face the weaknesses of life, death, disease, hunger, flood, and failure, through psychological support during tragedy, anxiety, and crisis. Therefore, religion gives certainty and meaning to humans in a naturalistic-looking world that seems to be full of unpredictable, fickle and tragic events. In the perspective of sociology, the function of religion through the celebration of Christmas is to nurture and cultivate solidarity among fellow individuals and groups. Solidarity is a part of religious social life that occurs in the midst of religious society, or, more precisely, solidarity is an expression of the behavior of religious people. Durkheim puts it in Ghazali (2011, p. 33) that the function of religion is to support and preserve the existing society. Religion is functional to the unity and social solidarity between the citizens of the Skouw Sae community. This last activity is based on a system of thought about the need to maintain the religious beliefs that make Jesus Christ the source of love.

The activity also supports customary house improvement activities in order to meet the safety needs of from all dangers in their natural environment, such as from other humans, earthquakes, tidal waves, excessive isolation and protection from animals. Through this celebration, it is expected to maintain relationships with traditional houses that are believed to be the house for ancestral spirits. Therefore, this ritual activity is a manifestation to guard and express their fear and respect to the «subtle creatures». Such actions express their acknowledgment of the presence and power of «subtle,» which is nothing but an act of good relationships between humans and the spirits. According to Hermann Strauus in Strelan $(1989$, p. 111), the spirits of good people and the supernatural powers of the traditional religion encourage the realization of the golden age of salvation and peace and a life of long-awaited happiness. It is also found in Maring Tsembaga. According to Rappaport (1971, pp. 226-235), the spirit of the ancestors will always protect and give strength to their surviving offspring. Thus, 
all participation in the above rituals is seen as a sacralization of social status changes or as the separation of one social role from the interference of other social roles. The rituals that are carried out collectively serve as the arena of a repetitive congregation. Hence, it will lead to increased bonding of group sentiment and social solidarity (Suhardi 2009, p. 2). Meanwhile, according to Merton in Kaplan et al (2002: 80), the ceremony serves to strengthen the identity of the group. The above explanation is also in line with Malinowski>s opinion in Kuper (1996, p. 29) showing that ritual act really form an integrated unity and these elements have a function to maintain the safety of life that this community struggled for collectively.

The collective desire is a common life within a social community as a clan or tribe. Therefore, the salvation in this particular community and Papua or Melanesia in general, according to Fugman in Alua (2006, p. 50), is obtained primarily by establishing, organizing, maintaining, and extending the relations system in an appropriate manner. The system of relationships forms a network and supports life and growth. Therefore, everything in the form of individual affairs is organized through groups, such as marriage, death, certain cases, and others.

All of the above activities will invite the attention of every member of the community because the success of its action is determined by everyone's involvement. This is, according to Alua (2006, p. 49), in line with the concept of salvation in the context of the people in $\mathrm{Pa}$ pua. According to him, to achieve salvation in the world, a relationship is needed in the community. The relations that must be maintained are relationships with others, including with the residents of village community who are now settled in some areas in PNG because of marriage bonds. Similarly, the relations with spirits and natural surroundings are essential as well. Those relations are done integrally. If they neglect one aspect of the relation, it will intervene the ideals of safety. Finally, this activity also supports the system of ideas about the need to perpetuate the beliefs of traditional houses as a place to live the spirit of the ancestors.

The economic activity also supports family relaxation activities during school holidays to meet the needs of individual for enjoyment. The limited entertainment facilities within the village area encourage these villagers to do family picnics during school holidays and meet with relatives and traditional leaders in the area. On one hand, this activity is to relieve the pressure of life>s sadness or work pressure. On the other, it can bring closer relationships among family members, relatives and customary leaders in the region. The goal is to generate a change of feelings on all involved parties. The main characteristic is the presence of joyful feeling which allows others to join in the same action and carry out the action together. Therefore, the function of the meeting on this activity is to bring them into contact with each other, renew social relations and maintain solidarity among them. The excitement has a function to eradicate particular sentiment system toward others and to manage conformity to the needs of those involved. Finally, these activities serve to pass on the idea of the behavior of kinship systems in this community.

The cross border activities also support the visit on the cemetery construction of graveyard, the traditional home improvement and coronation Ondoafi with the aim of meeting the needs of relaxation through traditional dance. The dance is a symbol system that creates the local community to help resolve the fulfillment of basic and institutional needs. The symbol system generated during their daily activities is used to validate, organize and guide their behavior in accordance with the cultural values of local communities. People are expected to jointly integrate as a kinship of some communities. The integration of motion similarity is embodied in the dance steps and singing which are sung together. Through this activity, the history of their ancestors from Wutung to Skouw Sae is retold. It creates a sense of belonging among them. The activity helps them to remind each other that 
they come from the same origin. Therefore, they can help each other and prevent child marriage among close family members (between generations one to three). This activity also serves as a medium of communication and media expression of life lived by both communities. According to Sedyawati (1980, p. 6), another educational function is for channeling creativity, needs for security, excessive energy and stress. It can also serves as a means of socialization, worship tool, delivering ideas, recreational facilities and forming a sense of group. This last activity is to preserve the dance as a symbol of origin for residents of the village community.

The activity supports the gifts exchange between Skouw Sae and Wutung women which functions to fulfill the needs to relax and maintain the relationship between those who still have a family relationship. This is based on the grounds that after getting married and followed her husband, wives are busy with domestic affairs, reproduction, and the economy so they rarely meet. Moreover, in line with the concept of salvation in this community, family relationship should be maintained and enhanced in the form of frequent visits. This opportunity is also used to control the application of the rule prohibiting marriage between their children, especially their first to third generations because it will give birth to a disabled child. It also controls the lives of their relatives who live separately, in order to demand payment of the compensation to the family of their husbands, in case of unwanted things happen. In addition, through this activity, they can renew social relations and to maintain solidarity among them. This activity also maintains a system of thought about the importance of maintaining close relations of female sibling of the two separate communities where they live in different countries.

The cross border activity also supports the activities of the friendly match to commemorate the anniversary of PNG in order to meet the needs of relaxation through football and volleyball matches. The education function is to maintain relations of both types of sports that are often played in Sunday afternoon. Because the moment is also used as a test event to determine the progress of achievement of the activities which have been conducted jointly in order to improve the performance of both villages teams in Muara Tami District. According to Boelaars (1987, p. 77), the need for freedom makes them fond of exciting crowd, including through this friendly match where they can express and enjoy the excitement together. It also gives more prestige to someone who is credited with contributing to the victory on either side. In addition, through this activity, they can renew social relations and to maintain solidarity and togetherness among them.

In fulfilling the needs of building closer relationship between the heads of the village to maintain their roles in improving the social welfare of its citizens, they formulate a medium-term action plan for development. The proximity of the two villages can build a culture of participation through the involvement of all citizens in the election of the village head, planning, implementation and supervision of the village development program. The program also encourages the need for education to fill the needs of the formal structure of village government. In addition, through this activity, they can renew social relations and to maintain solidarity among them. This activity eventually passes system based on the idea of the need to maintain the village government system consisting of several adjacent clans in civic life.

From the social, economic and cultural aspects, cross-border movement is also done to meet the needs of the two communities for a closer kinship through the use of the nickname term in Wutung community. Community in Skouw Sae village will call communities of Skouw Mabo, Skouw Yambe, Wutung, and villages around Vanimo as Kitorang (us), and will refer to other community members who come to their cultural territory as dorang (them). The word of dorang is useful for maintaining social distance and simultaneously distinguishing them from the in group. It can strengthen the sense of the in group from the marriage, and 
not infrequently loosen the relationship to other groups outside the two communities. Social distance between Kitorang and dorang is highly dependent on the social approach that exists in the process of social interaction. The communication is built by outside groups, including government officials who serve in the cultural area. The proximity and approach through the right entrance is not uncommon to categorize as out group and in group. Therefore, it could establish a harmonious and pleasant life in all activities. The meaning of dorang (out group) may be merged into Kitorang (in group). Within that context, it is necessary to understand and accept each other in a variety of interests. If these factors cannot be realized in the interaction of social life, a seed source of open conflict between local people and migrants in the region can occuer. In addition, through this activity, they can renew social relations and to maintain solidarity among them. This activity eventually creates systems of the needs to strengthen the notion of kinship between the two communities.

Finally, the activity is conducted to meet the growing needs of individuals through the inheritance of knowledge for men who originally perform in the traditional house of tangfa and has moved on family life. This is because a man has a major role in the lives of family, clan and community. There are two types of inheritance of knowledge. Firstly, it deals with the skills of a technical nature such as farming, the use of plants (for food, clothing and board), hunting, farming, gathering, and fishing. Secondly, the knowledge which deals with values of kinship, trust, belief, customs administration, the system of marriage, dowry, compensation from the husband's family to his wife's family and others. Meanwhile, this also deals with the inheritance of the knowledge of women regarding reproductive and domestic activities because they would follow their husband after marriage. The activity is a form of citizen awareness about the importance of the provision for a man and woman to maintain the continuity of family, clan and community in general.
According Poespowardojo (1989, p. 121), this effort will create a system of community life for the better. In addition, through this activity, they can renew social relations and to maintain solidarity among them. The above efforts are based on a system of thought about the importance of preparing a man with basic and advanced knowledge about the local culture as the heir of the family, the clan, as well as the community in general.

\section{CONCLUSION}

Based on the discussion, it can be concluded that the economic functions of cross-border activity done by community residents in Skouw Sae village, Muara Tami District, Jayapura to Wutung Village PNG is to meet the basic and institutional needs as well as a system of ideas of citizens. The activity is also done to create closer kinship between the people in two villages.

\section{REFERENCES}

Alua, A.A., 2006. Karakteristik Dasar Agama-Agama Melanesia. STFT Fajar Timur, Jayapura.

Amelina, A. ed. 2012. Beyond methodological nationalism: Research methodologies for cross-border studies (Vol. 24). Routledge.

Bandiyono, S., 2004. Mobilitas Penduduk Di Perbatasan Papua-PNG, Sebuah Peluang dan Tantangan. Pusat Penelitian Kependudukan Lembaga Ilmu Pengetahuan Indonesia (PPK-LIPI), Jakarta.

Bertrand, O., \& Betschinger, M. A., 2012. Performance of domestic and cross-border acquisitions: Empirical evidence from Russian acquirers. Journal of Comparative Economics, 40(3), pp. 413-437.

Blesia, J. U., \& Ratang, W., 2016. Indigenous Wisdom for Deloping Economic Life Case of Yokari People, West Papua. Komunitas: International Journal of Indonesian Society and Culture, 8 (2), pp. 275-284.

Budisanto, Y., 1986., Antropologi Politik Georges Balandier. CV. Rajawali, Jakarta.

Cohen, J. H., 2004. The Culture of Migration in Southern Mexico. University of Texas Press, USA.

Djohan, E. \& Herry Y., 1998. Kondisi Daerah Perbatasan Indonesia-Malaysia di Kalimantan Timur, in Raharto, R., (ed) Mobilitas Penduduk Wilayah Perbatasan Indonesia-Malaysia di Kalimantan Timur. Puslitbang Kependudukan dan Ketenagakerjaan LIPI, Jakarta.

Ghazali, A. M., 2011. Antropologi Agama Upaya Memahami Keragaman Kepercayaan, Keyakinan 
dan Agama. Penerbit Alfabeta, Bandung.

Ghosh, S., 2011. Cross-border activities in everyday life: the Bengal borderland. Contemporary South Asia, 19(1), pp. 49-6o.

Herskovits, M. J., 2006. "Organisasi sosial: Struktur Sosial" dalam Pokok-pokok Antropologi Budaya Edit T.O. Ihromi. Yayasan Obor Indonesia, Jakarta.

Kaplan, D., \& Robert A. M., 2002. Teori Budaya Pengantar PM. Laksono. Pustaka Pelajar, Yogyakarta.

Keesing, R. M., 1998. Antropologi Budaya Suatu Perspektif Kontemporer. Penerbit Erlangga, Jakarta.

Kuper, A., 1996. Pokok dan Tokoh Antropologi. Penerbit Bhratara, Jakarta.La Pona. 1996. Faktor yang Mempengaruhi Migrasi Internasional (Legal) RI - PNG (Studi Kasus: di Desa Skouw Yambe dan Skouw Mabo). Universitas Cenderawasih, Jayapura.

Lane, J. E., \& Kinser, K., 2011. Reconsidering privatization in cross-border engagements: The sometimes public nature of private activity. Higher Education Policy, 24(2), p. 255-273.

Lee, E., 1966. A Theory of Migration. Demography, 3 (1), pp. 47-57.

Lundquist, K. J., \& Trippl, M., 2013. Distance, proximity and types of cross-border innovation systems: A conceptual analysis. Regional Studies, 47(3), pp. 450-46o.

Malinowski, B., 1944. A Scientific Theory of Culture and Other Essays. University of North Carolina Press, Chapel Hill.

Malinowski, B., 1948. Magic, Science and Religion and Others Essays. The Free Press, Glencoe.

Mansoben, J. R., 2008. "Perbatasan RI-PNG Butuh Kearifan Lokal", Makalah disampaikan pada Rapat Kordinasi Teknis (Rakornis) Penanganan Wilayah Perbatasan RI-PNG, yang diselenggarakan Badan Perbatasan dan Kerjasama Daerah Propinsi Papua di Jayapura.

Meuleman, M., \& Wright, M., 2011. Cross-border private equity syndication: Institutional context and learning. Journal of Business Venturing, 26(1), pp. 35-48.

Newman, D., 2011. Contemporary research agendas in border studies: An overview. The Ashgate research companion to border studies, pp. 33-47.

Pitelis, C. N., \& Teece, D. J., 2010. Cross-border market co-creation, dynamic capabilities and the entrepreneurial theory of the multinational enterprise. Industrial and Corporate Change, 19(4), pp. 1247-1270.

Poespowardojo, S., 1989. Strategi Kebudayaan Suatu Pendekatan Filosofis. Penerbit PT Gramedia, Jakarta.

Rappaport, R. A., 1971. Ritual Regulation of Environ- vental Relation among a New Guinea People, in Cohen Y. A. (ed) Man in Adaption: The Institutional Frame work, Aldine Atherton, New York..

Sedyawati, E., 1980. Pengantar dalam beberapa Masalah Perkembangan Kesenian Indonesia Dewasa ini. Fakultas Sastra Universitas Indonesia, Jakarta.

Setiawan, B., \& Herry Y., 1998. Proses Mobilitas Penduduk di Wilayah Perbatasan Indonesia Timor Leste, in Raharto, A. (ed) Mobilitas Penduduk Wilayah Perbatasan Indonesia-Malaysia di Kalimantan Timur. Puslitbang Kependudukan dan Ketenagakerjaan LIPI, Jakarta.

Siagian, J., 1995. Mobilitas Peduduk Lintas Perbatasan: Kasus Kalimantan Barat-Serawak. Majalah Prisma, 1 Januari.

Soekardjo, R. G., 1987. Antropologi Politik, Suatu Orientasi. Penerbit Erlangga, Jakarta.

Strelan, G. J., 1989. Kargoisme di Melanesia Suatu Studi tentang Sejarah dan Teologi Kultus Kargo. Pusat Studi Irian Jaya, Jayapura.

Suhardi. 2009. Alam-Religi Solidaritas Sosial di Papua dan Jawa: Terawang Antropologi. Scholarship for Intercultural Studies Program/Program Beastudi Kajian Antarbudaya Pusat Studi Asia Pasifik Universitas Gadjah Mada, Jogyakarta.

Suparlan, P., 1995. "Keaneragaman Kebudayaan Irian Jaya, Strategi Pembangunan dan Transformasi Orang Irian ke Dalam Masyarakat Indonesia”, dalam Proseding Seminar Membangun Masyarakat Irian Jaya. Puslitbang Kependudukan dan Ketenagakerjaan Lembaga Ilmu Pengetahuan Indonesia, Jakarta.

Weidenfeld, A., 2013. Tourism and cross border regional innovation systems. Annals of Tourism Research, 42, pp. 191-213.

Wenehen, A., 200o. Sosio-Kultural Pertanahan Di Kawasan Perbatasan Papua: Studi Pada Orang Walsa dan Fermanggem Di Kecamatan WarisJayapura. Kerjasama Mennonite Central Committee (MCC) Canada dan Uncen, Jayapura.

Xheneti, M., Smallbone, D., \& Welter, F., 2013. EU enlargement effects on cross-border informal entrepreneurial activities. European urban and regional studies, 20 (3), pp. 314-328.

Xia, J., 2011. Mutual dependence, partner substitutability, and repeated partnership: the survival of cross-border alliances. Strategic Management Journal, 32(3), pp. 229-253.

Zaelany, A, A., \& Augustina., 1995. Mobilitas Penduduk Kepulauan Sangihe-Talaud: Tinjauan Sejarah, in Raharjo, A. (ed) Migrasi Kembali Orang Sangir-Talaud dari Pulau-pulau di Wilayah Filipina. Puslitbang Kependudukan dan Ketenagakerjaan LIPI, Jakarta. 